\title{
Cooperators Involvement and Satisfaction on Cooperative Society Housing Activities in Jos Plateau State, Nigeria
}

\author{
Aishatu Adamu Mazadu ${ }^{1}$, Maryam Salihu Muhammad ${ }^{2}$, Muhammad Usman Adekunle ${ }^{2}$
}

${ }^{1}$ University of Jos

P. M. B 2084, Jos, Nigeria

${ }^{2}$ Abubakar Tafawa Balewa University

Dass road, P. M. B. 0248, Bauchi, 740272, Nigeria

DOI: $10.22178 /$ pos. $76-9$

JEL Classification: 018

Received 21.10.2021

Accepted 25.11.2021

Published online 30.11.2021

Corresponding Author:

Aishatu Adamu Mazadu

aishatumazadu@gmail.com

(C) 2021 The Authors. This

article is licensed under a

Creative Commons Attribution

4.0 License @ (1)
Abstract. This research aims to assess cooperators involvement and satisfaction with housing activities in Plateau State, Nigeria, to measure their degree of influence on housing activities. The study was based on various questionnaire survey methods conducted on institution-based cooperative societies engaged in suitable housing activities. The data was collected from Jos University Teaching Hospital JUTH multipurpose cooperative society cooperators and analysed using mean ranking descriptive statistical tools. Multiple regression was conducted. Regression model summary and the ANOVA result were obtained. The model produced an overall R-value of 0.421 and an $R^{2}$-value of 0.177 with F-statistics of 32.685 , which are significant as indicated by a p-value of 0.000 . The two independent variables included in the study explain about $17.7 \%$ of the variation in housing activities. This shows that both involvement and satisfaction of cooperators influenced housing activities. The study recommended that cooperators be more involved in all housing activities from the initial stage to the completion for a more positive outcome and ensure their utmost satisfaction based on their housing demand. This will motivate them and increase patronage of the cooperative society for their housing needs at all times.

Keywords: involvement; satisfaction; cooperators; cooperative society; housing activities.

\section{INTRODUCTION}

Housing is one of the three basic needs of man, and it is the most essential for the physical survival of man after the provision of food. It is collectively acknowledged as the second most basic human need after food and is a significant economic asset in every nation [4]. The provision of decent and qualitative housing for the teeming population had been a fundamental objective of various governments across the world. Despite this, the housing problem persists from quantitative to qualitative, particularly in developing countries [8]. For example, authors [18] asserted that to adequately house the urban population in Nigeria, a conservative figure of 409227 housing units should have been constructed in 1990 due to negligence the number rose to 783042 units in 1995; 1333176 units in the year 2000; 1543 318 units in 2003, 2171603 units in 2010, 17 million units in 2012 and 20 million units in 2018 [17]. Hence the need for all the stakehold- ers to join hands in providing housing needs for the populace.

Plateau State's housing deficit is estimated between 450000 to 500000 for the entire state, with about 900000 residents based on the 2006 census and 240000 debts for the more excellent Jos's master plan. Since the State low-cost housing units of the 1970s and the Shagari mass housing scheme in 1980's not much has been done in terms of direct provision of mass housing units for citizens in Plateau state, except for this present administration that intends to provide about 50800 housing units across the state. Thus, the federal government has acquired land for mass housing to citizens in the state, yet no positive result has been recorded [16]. Moreover, frequent crises in the state led to the destruction of houses and properties without any proper plan for erecting new ones or rehabilitating their old ones. This increases demand for places that outweigh its supply in the state. The resultant effect 
of this shortfall led to high rental prices, overcrowding, uncontrolled squatter settlements and slums. The situation is worrisome. Like any other part of the country, Plateau State has a high demand for housing that outweighs the supply, hence the need for other bodies to curb this menace.

However, one of the solutions being explored by underprivileged groups is cooperative societies housing. It has been said to have played vital roles in housing in some countries, but the concern is the activities of cooperative societies in the area of housing in Nigeria [29]. Author [6] suggested that cooperative societies can be a viable mechanism in positively impacting funding housing in urban centres, especially for public institutions in Nigeria. It can assist the government in meeting the targets set under the 1991 National Housing Policy to ensure the underprivileged people gain access to decent housing.

\section{Literature Review}

Author [2] stated that cooperative societies are formed principally to meet peoples' mutual needs based on the idea that a group of people can achieve goals that none of them could achieve alone. The formation and purpose of cooperative societies are not to meet unessential collective or individual needs. Instead, it aims to provide necessities that otherwise might take a long time to implement or are completely unaffordable without assistance. Housing activities by cooperative societies are various methods, techniques, and processes that assist co-operator's in building their own houses or directly purchasing the homes to solve their housing problems. Unlike the government and profit-oriented private sector, the cooperative method of housing emphasises end users' participation from the commencement of the process [27]. This is made possible based on the principles and values that govern the operation and activities of cooperative societies.

Authors [13] revealed that the cooperative housing approach yielded little progress in alleviating the housing problem. Author [5] submitted that the housing cooperatives are not only instruments of collective ownership but are also mechanisms of housing finance and construction in the developing world. On the other hand, author [19] expressed the contrary opinion that cooperative societies have yet to make any signify significant- ly impact revealed that housing cooperatives have provided adequate housing for women in Nairobi, Kenya. Author [30] asserted that SACCO had done tremendously well in the housing sector, given the challenging environment in which it operates. Author [20] submitted that despite the seeming failure of cooperative housing initiatives in the country, the same societies are still viewed as instrumental vehicles for facilitating the poor to access decent housing, especially in the urban context in Tanzania. Authors [14] submitted that housing provision through cooperatives exhibits affordability through bulky procurement of construction materials and technical expertise, involvement of members in the do-ityourself and improved efficiency through repetitive works in house construction. Authors [25] stated that housing activities by cooperative societies include land acquisition, houses developed and allocated to co-operator's at a subsidised rate, building materials procurement, direct housing purchase, and direct private project and providing loans for housing to co-operator's. Efforts directed at meeting the housing objectives of cooperative members have resulted in different strategies depending on the goal, financial capacity, and level of assistance received [27].

Authors [9] stated that involvement is the act of participating in cooperative societies activities or an act of including co-operators in activities of having co-operators in cooperative societies' activities. It is crucial to the adequate performance of a harmonious society, which is also pertinent to their goal attainment. Author [21] revealed that the inclusion of poor people through decision-making builds commitment to change since people gain self-confidence and a sense of personal control through participation. On the other hand, lack of involvement creates powerlessness among poor people. The involvements of cooperators in housing activities decisions are crucial to the achievement of cooperative societies housing. Author [20] stated that co-operators should be involved in the decision regarding housing activities such as the decision on the location of the site to purchase, on how to finance housing sector activity, on type of infrastructure to provide on land, the decision to carry out actual construction, processes of land and building documentation deciding, on professionals to hire, deciding on the size of plot to purchase, deciding on whom to buy land from and how much to pay for the ground etc. Authors [23] submitted that 
co-operator's involvement in housing decisions has been a significant driving force for the favourable and favourable performance of the cooperative society housing. Authors [1] averred that the involvement of cooperative societies in housing activities has been successful.

Author [22] stated that satisfaction is the degree of pleasure provided by the goods and services of a company as measured by the number of repeat customers. It is also the quality or state of being satisfied or contentment. Author [26] asserted that cooperators satisfaction is a precursor of improved performance and cooperator retention for any cooperative society. Member's goals, what they desire from their cooperatives are critically related to why they joined the joint in the first place. These goals also affect member satisfaction with the cooperative, commitment to it, and participation in its activities. This definition clarifies that satisfaction is a function of perceived performance and expectations. The ability of a cooperative to meet its members' expectations depends on whether management effectively evaluates membership needs [2]. Author [7] reported that cooperators' attitudes towards their cooperatives significantly impact their cooperative participation behavioural intentions. Author [24] submitted that achieving high cooperators satisfaction requires a harmonious society to continually monitor and examine their cooperators' experiences, opinions, and suggestions. Authors [4] reported that cooperators expressed their satisfaction with housing cooperative loans than the National housing fund (NHF). Author [12] also revealed that cooperators expressed their satisfaction with an interest rate, affordability, transaction cost, availability and collateral for housing finance. However, in housing activities, cooperators need to be satisfied with all processes, methods and techniques of housing activities from the initial stage to the completion based on demand.

\section{METHODS}

This research was carried out in Plateau State; the quantitative approach was adopted, descriptive survey design. The study's target population was co-operators of Jos University Teaching Hospital (JUTH) Multipurpose Cooperative Society. The sample frame obtained from JUTH Multipurpose cooperative society is 3000 cooperators, but only 2200 members are active; therefore, only the active members were considered for this study. The sample size of 327 used for this research was chosen using the [10] sample table. Multistage sampling was used. This involved taking samples in stages using smaller and smaller units at each step [3]. Then simple random sampling technique was also adopted. This is because it gives each equal chance or probability of being selected, reducing selection bias [3]. Three hundred twenty-seven closeended questionnaires were distributed to the cooperators of the cooperative societies to generate data for the study.

\section{RESULTS AND DISCUSSION}

The reliability of the measurement scale was assessed using the recommended minimum Cronbach's alpha coefficient of 0.7. The Cronbach's Alpha test was conducted on the questionnaire constructs. The test revealed that involvement and satisfaction have good internal consistency with Cronbach's Alpha of 0.710 and 0.723 each, while housing activities have an internal consistency with Cronbach's alpha of 0.753 . This is shown in table 1 .

Table 1 - Cronbach's Alpha Value of questionnaire constructs

\begin{tabular}{|l|c|c|c|c|}
\hline No & Variables & Item Statistics / No. of construct & Cronbach's Alpha Value & Reliability status \\
\hline 1 & Involvement & 11 & 0.71 & Acceptable \\
\hline 2 & Satisfaction & 8 & 0.72 & Acceptable \\
\hline 3 & Housing activities & 7 & 0.75 & Acceptable \\
\hline
\end{tabular}

Effects of cooperators involvement and satisfaction on housing activities by cooperatives societies in the study area were determined using Multiple Regression Analysis (MRA). The enter method was used with housing activities as the dependent variable while involvement and satisfaction were the independent variables. The regression model was specified to produce the model summary and analysis of variance (ANOVA) to determine the independent variables' influences or predictors on the dependent 
variable. The model summary and ANOVA are presented in table 2 . The model produced an overall R-value of 0.421 and an $\mathrm{R}^{2}$-value of 0.177 with F-statistics of 32.685, which are significant as indicated by p-value of 0.000 . The two independent variables included in the study explain about $17.7 \%$ of the variation in housing activities.

Table 2 - Model Summary and ANOVA

\begin{tabular}{|c|c|c|c|c|c|c|c|c|c|}
\hline \multirow{2}{*}{ Model } & \multirow{2}{*}{$\mathrm{R}$} & \multirow{2}{*}{$\mathrm{R}^{2}$} & \multirow{2}{*}{ Adjusted $\mathrm{R}^{2}$} & \multirow{2}{*}{ Std. Error of the Estimate } & \multicolumn{4}{|c|}{ Change Statistics } \\
\cline { 6 - 10 } & & & & & $\mathrm{R}^{2}$ Change & F Change & df1 & $\mathrm{df} 2$ & Sig. F Change \\
\hline 1 & $.421 \mathrm{a}$ & .177 & .172 & .26410 & .177 & 32.685 & 2 & 304 & .000 \\
\hline
\end{tabular}

Table 3 shows the regression coefficients of the independent variable, indicating the individual contribution of each of the independent variables on the dependent variable. The result shows that the coefficients were all significant with $p$-values of 0.000 testing on a $5 \%$ low significance level.

Table 3 - Coefficients

\begin{tabular}{|c|c|c|c|c|c|c|c|c|c|c|c|}
\hline \multirow{2}{*}{\multicolumn{2}{|c|}{ Model }} & \multicolumn{2}{|c|}{$\begin{array}{l}\text { Unstandardised } \\
\text { Coefficients }\end{array}$} & \multirow{2}{*}{$\begin{array}{c}\begin{array}{c}\text { Standardised } \\
\text { Coefficients }\end{array} \\
\text { Beta }\end{array}$} & \multirow{2}{*}{$\mathrm{T}$} & \multirow{2}{*}{ Sig. } & \multicolumn{3}{|c|}{ Correlations } & \multicolumn{2}{|c|}{$\begin{array}{l}\text { Co linearity } \\
\text { Statistics }\end{array}$} \\
\hline & & B & Std. Error & & & & $\begin{array}{l}\text { Zero- } \\
\text { order }\end{array}$ & Partial & Part & Tolerance & VIF \\
\hline \multirow[t]{3}{*}{1} & (Constant) & 1.010 & .123 & & 8.211 & .000 & & & & & \\
\hline & satisfaction & .312 & .053 & .318 & 5.898 & .000 & .372 & .320 & .307 & .930 & 1.075 \\
\hline & involvement & .173 & .046 & .204 & 3.777 & .000 & .288 & .212 & 197 & .930 & 1.075 \\
\hline
\end{tabular}

The result shows that co-operator's involvement has a relationship contribution of 0.204 magnitudes on housing activities.

This means that for a unit increase in cooperator's involvement, there is a corresponding increase of $20.4 \%$ in housing activities. Moreover, co-operator's satisfaction with housing activities in Jos North as indicated by standardised beta coefficient of 0.318 . This means that xo for a unit increase in co-operator's satisfaction, there is a corresponding increase of $31.8 \%$ in housing activities. This means that the higher the level of co-operator's satisfaction with housing activities in Jos North, the higher the housing activities and vice versa.

\section{CONCLUSIONS}

The study came when the government was trying to make housing available to its citizens. The survey findings indicated that co-operators are fully involved, very well satisfied with housing activities by their cooperative society. The study demonstrated a significant effect of cooperative societies' involvement and satisfaction with housing activities. A regression analysis was conducted, and it indicated a summary of regression and ANOVA model that fitted well and good as it produced strong $\mathrm{R}^{2}$ and $\mathrm{F}$-statistics values. Therefore, co-operators should be more involved in all processes of housing activities from the initial stage to the completion for a more positive outcome. This will motivate them and increase patronage of the society for their housing needs at all times.

Co-operator's satisfaction in all activities is paramount. Therefore, cooperative societies should look into all housing activities and ensure the utmost satisfaction of co-operators based on their demand and needs.

Cooperative societies need to source funds outside to hasten housing activities

Government should come in to assist cooperatives with the fund at a low-interest rate to speed up housing activities since they are now considered an alternative mechanism in solving housing needs. 


\section{REFERENCES}

1. Adedeji, Y. M., \& Abiodun, O. O. (2012). An Evaluation of Accessibility of Low-Income Earners to Housing Finance in Nigeria. European Scientific Journal, 8(12), 80-95.

2. Dogarawa, A. B. (2010). The Role of Cooperative Societies in Economic Development. SSRN Electronic Journal. doi: 10.2139/ssrn.1622149

3. Easton, V., \& McColl, J. (n. d.). Statistics Glossary. Retrieved from http://www.stats.gla.ac.uk./steps/glossary/sampling.html

4. Farouk, B. U., David, I. J., \& David, O. A. (2014). Savings and Credit Cooperative Societies (SCCs): A Panacea to Accessing Funds for Housing Development to Workers of Public Institutions in Nigeria. Journal of Economics and Sustainable Development, 5(23), 135-148.

5. Ganapti, S. (2014). Housing cooperatives in the developing world. Hoboken: Routledge.

6. Gbadeyan, R. A. (2011). Private Sector's Contributions to the Development of the Nigerian Housing Market. Current Research Journal of Social Sciences, 3(2), 104-113.

7. Iruguthu, E. W. (2014). Factors that influence customer satisfaction in savings and credit cooperatives (saccos) in Kenya: A case study of Balozi Sacco (Masters thesis). Retrieved from http://erepo.usiu.ac.ke/bitstream/handle/11732/56/Emily.pdf?sequence=1\&isAllowed=y

8. Kabir, B., Bustani, S. (2009). A Review of Housing delivery efforts in Nigeria. Retrieved from http://www.gla.ac.uk/media/media_129767_en.pdf

9. Kadarisman, H., \& Suharyono, S. (2014). The Effect of Members Participation on Business SelfReliance and Members Welfare (Study on Cooperative Corporation in East Java Indonesia). Journal of Business and Management, 16(6), 15-21.

10. Krejcie, R. V., \& Morgan, D. W. (1970). Determining Sample Size for Research Activities. Educational and Psychological Measurement, 30(3), 607-610. doi: 10.1177/001316447003000308

11. Law Nigeria. (2018, April). University teaching hospitals. Retrieved from https://bit.ly/33nLigJ

12. Mahmud, S. M. (2011). An evaluation of the contributions of cooperative societies in housing finance to workers of tertiary institutions (Master's thesis). Retrieved from https://eprojecttopics.com/topic/4188-an-evaluation-of-the-contributions-of-cooperative-societies-inhousing-finance-to-workers-of-tertiary-institutions.html

13. Marunga, N., \& Mberengwa, I. (2014). The Effectiveness of the Housing Cooperative Approach in the Provision of Urban Housing in Bindura. ResearchJournali's Journal of Geography, 1(6), 1-23.

14. Mhekela, T., \& Kombo, H. (2015, December 3-4). Assessment of the contribution of housing cooperatives in the provision of affordable housing. Retrieved from

https://www.nhbra.go.tz/uploads/documents/sw/1471249494-X-

CONTRIBUTION\%200F\%20HOUSING\%20CO-

OPERATIVES\%20IN\%20THE\%20PROVISION\%200F\%20AFFORDABLE\%20HOUSING.pdf

15. Ministry of Commerce and Industry. (2019). About. Retrieved from https://bit.ly/3yhixh8

16. Ministry of housing and urban development. (2019). About. Retrieved from https://bit.ly/3D05dll

17. Moore, E, A. (2019). Addressing Housing Deficit in Nigeria: Issues, Challenges and Prospects. Economic and financial review, 57(4), 201-222.

18. Morakinyo, K. O., Okunola, A. S., Ogunrayewa, M. O., \& Dada, O. (2015). A Review of Private Sectors' Involvement in Urban Housing provision in Nigeria. International Journal of Civil Engineering, Construction and Estate Management, 3(2), 36-47.

19. Ndubueze, O. J. (2009). Urban housing affordability and housing policy dilemmas in Nigeria (Doctoral thesis). Retrieved from https://dev.humanitarianlibrary.org/sites/default/files/2013/08/Ndubueze09PhD.pdf 
20. Nguluma, H. (2016). Access to Housing through Cooperatives: Potentials and Challenges from Tanzania. International Journal of Humanities, Social Sciences and Education, 3(9). doi: 10.20431/2349-0381.0309012

21. Nyanda, M. M. (2013). Factors influencing empowerment of cooperative members in Tanzania: a case of Nyanza cooperative union, Mwanza region (Master's thesis). Retrieved from http://www.suaire.sua.ac.tz/bitstream/handle/123456789/453/MICHAEL\%20MAHENE\%20N YANDA.pdf?sequence=2\&isAllowed=y

22. Nyer, P. U. (2000). An investigation into whether complaining can cause increased consumer satisfaction. Journal of Consumer Marketing, 17(1), 9-19. doi: 10.1108/07363760010309500

23. Olabisi, A., Petronilla, O. I. (2011). Effect of members' participation on cooperativeperformance: a study of selected multipurposecooperative societies (mcs) in Awka South Lga of Anambrastate, Nigeria. International Journal of Multi-disciplinary research, 4, 117-126.

24. Olanda, J. (2006). Leadership Behaviour, Job satisfaction, Organisational Commitment, Service Quality and Customer Satisfaction in manufacturing sector (Master's thesis), University of Nairobi. Kenya.

25. Olayinka, C. O., Samuel, A. O., \& Olufemi, D. D. (2017). Empirical Determination of Co-operative Housing Intervention Methods in Lagos Metropolis. Covenant Journal of Research in the Built Environment, 4(1), 49-66.

26. Oliver, R. L. (1999). Whence Consumer Loyalty? Journal of Marketing, 63, 33-44. doi: $10.2307 / 1252099$

27. Oyalowo, B. (2018). An assessment of co-operative societies and housing supply in Lagos State (Doctoral thesis). Retrieved from https://ir.unilag.edu.ng/bitstream/handle/123456789/3249/4_Thesis.pdf?isAllowed=y\&seque nce $=2$

28. QuestionPro. (n. d.). Likert scale questions with examples. Retrieved from https://www.questionpro.com/article/likert-scale-survey-questions.html

29. Sazama, G. W. (2000). Lessons from the History of Affordable Housing Cooperatives in the United States: A Case Study in American Affordable Housing Policy. The American Journal of Economics and Sociology, 59(4), 573-608.

30. Wood, D. S (2019, June 11). The Role of Savings and Credit Cooperative Organisations in Kenya's Housing Finance Sector. Retrieved from https://www.urbanet.info/savings-and-creditcooperative-organisations-inkenya/\#: :text=Savings\%20and\%20Credit\%20Cooperative\%200rganisations\%20play\%20a,f or\%20housing\%20security $\% 20 \mathrm{in} \% 20$ Kenya.\&text=Their\%20importance $\% 20 \mathrm{in} \% 20$ the $\% 20$ ho using,SACCOs\%20and\%20housing\%20cooperative\%20networks 